Katarzyna OKRĘGLICKA

Joanna RAJCZAK

Monika TRAFALSKA

Uniwersytet Łódzki

\title{
BUDŻET OBYWATELSKI JAKO NARZĘDZIE KREOWANIA PRZESTRZENI REKREACYJNEJ ŁODZI
}

\section{Wstęp}

Czas wolny odgrywa bardzo ważną rolę w życiu każdego człowieka. Obejmuje wszelkie zajęcia, którym człowiek oddaje się z własnej woli, np. w celu odpoczynku, rozrywki, poszerzenia wiedzy lub kształcenia (niezawodowego), czy też dobrowolnego udziału w życiu publicznym, po uwolnieniu się od obowiązków zawodowych, rodzinnych i społecznych (Migdał, 2011). Aby aktywnie spędzać czas wolny człowiek często wykorzystuje przestrzeń rekreacyjną miasta, w którym żyje. Są to m.in. parki miejskie, siłownie plenerowe, place zabaw czy boiska wielofunkcyjne. Miejsca te zostały sfinansowane $\mathrm{z}$ różnych środków, ale część tych terenów bądź obiektów powstała w ramach budżetu obywatelskiego.

W niniejszym artykule skupiono się na określeniu znaczenia budżetu obywatelskiego $\mathrm{w}$ kreowaniu przestrzeni rekreacyjnej Łodzi, sprecyzowaniu liczby i rozmieszczenia terenów oraz obiektów rekreacyjnych finansowanych z budżetu obywatelskiego w latach 2014-2016, a także ustaleniu, w jaki sposób i przez kogo są one wykorzystywane oraz jaka jest percepcja użytkowników tych terenów (na pięciu wybranych przykładach - po jednym z każdej dzielnicy miasta).

Przed przeprowadzeniem badań autorki sformułowały następujące hipotezy:

1. Budżet obywatelski w dużym stopniu przyczynia się do kreowania przestrzeni rekreacyjnej Łodzi. 
2. Mieszkańcy miasta podczas głosowania w ramach budżetu obywatelskiego najchętniej wybierają zadania związane $\mathrm{z}$ zagospodarowaniem przestrzeni rekreacyjnej.

3. Korzystający $z$ terenów rekreacyjnych finansowanych $z$ budżetu obywatelskiego nie mają świadomości tego, z jakich środków zostały one utworzone.

Do przeprowadzenia badań terenowych autorkom posłużyły następujące metody badawcze: inwentaryzacja obiektów powstałych w ramach budżetu obywatelskiego, obserwacja, badania ankietowe oraz dokumentacja fotograficzna. Wykorzystane narzędzia to: karta inwentaryzacji, karta obserwacji, kwestionariusz wywiadu, a także aparat fotograficzny.

\section{Istota i zasady działania budżetu obywatelskiego}

Budżet obywatelski (partycypacyjny) to proces decyzyjny, w ramach którego mieszkańcy współtworzą budżet danego miasta, tym samym współdecydując o dystrybucji określonej puli finansowych środków publicznych (Kębłowski, 2013).

Pierwszy pełny proces tworzenia budżetu obywatelskiego (partycypacyjnego) rozpoczął się $\mathrm{w}$ latach 90 . ubiegłego wieku w brazylijskim mieście Porto Alegre, jednym z centrów opozycji przeciwko wojskowej dyktaturze, która rządziła krajem w latach 1964-1985. Walka z reżimem w dużym stopniu koncentrowała się na polityce miejskiej i pozwoliła licznym ruchom wykształcić wiele strategii współpracy z mieszkańcami i wypracować skuteczne narzędzia partycypacyjne. Jeszcze przed pierwszymi demokratycznymi wyborami lokalnymi po upadku dyktatury w 1985 r. zaproponowano przeprowadzenie inicjatywy, która wkrótce miała zyskać nazwę budżetu partycypacyjnego. Na poparcie władz trzeba było czekać do wyborów w 1989 r., wygranych przez lewicową Partię Robotników. Budżet partycypacyjny został więc wprowadzony jako inicjatywa oddolna, która zyskała silne poparcie władz lokalnych. Po długim okresie przygotowawczym uzyskał swój pierwszy kształt (później rokrocznie nieznacznie modyfikowany) w latach 1991 i 1992. Projekt okazał się wielkim sukcesem i wkrótce zyskał ogromną popularność w Brazylii - do 2008 r. wprowadziło go ok. 200 tamtejszych miast, obejmując ponad $44 \mathrm{mln}$ mieszkańców. Upowszechnił się kolejno w Ameryce Południowej (przynajmniej 510 miast zaangażowanych w budżet obywatelski w 2010 r.), Europie (200 miast), Afryce, Azji i Ameryce Północnej, tym samym zyskując status globalny. W Polsce budżet oby- 
watelski wprowadzono po raz pierwszy w 2011 r. w Sopocie (Kębłowski, 2013). W Łodzi pierwsze głosowanie $w$ ramach budżetu obywatelskiego odbyło się w $2013 \mathrm{r}$. Władze miasta przeznaczyły na ten proces najwyższą kwotę ( $20 \mathrm{mln}$ zł) spośród wszystkich miast, które wprowadziły zasadę budżetu obywatelskiego w Polsce (Kraszewski, Mojkowski, 2014).

Badacze budżetu obywatelskiego wyodrębniają kilka podstawowych i kluczowych, ściśle powiązanych kryteriów, które odróżniają go od innych praktyk angażujących mieszkańców. Po pierwsze jego integralną częścią jest publiczna dyskusja mieszkańców, którzy na przynajmniej jednym z etapów inicjatywy spotykają się i deliberują na specjalnie do tego celu powołanych zebraniach czy forach. Dialog między mieszkańcami jest kluczowy dla ich późniejszej współpracy z urzędnikami. Po drugie dyskusja w ramach budżetu obywatelskiego dotyczy jasno określonych, ograniczonych środków finansowych. Po trzecie budżet partycypacyjny nie odnosi się wyłącznie do dzielnicy, osiedla lub instytucji - przynajmniej na jednym z etapów sięga również poziomu ogólnomiejskiego. Po czwarte jego wyniki są wiążące, bowiem propozycje inwestycyjne wybrane przez mieszkańców zostają zrealizowane. Mieszkańcy otrzymują informację zwrotną dotyczącą zarówno projektów wybranych w ramach dyskusji, jak i tych, które zostały odrzucone. Po piąte budżet obywatelski to proces długofalowy, a nie jednorazowy - jest organizowany rokrocznie przez lata (Kębłowski, 2013).

\section{Wyniki przeprowadzonych badań}

W Łodzi w ramach głosowania dotyczącego budżetu obywatelskiego (BO) wyodrębnia się podział na zadania ogólnomiejskie oraz zadania lokalne dla poszczególnych dzielnic (Bałuty, Górna, Polesie, Widzew, Śródmieście). Każdy mieszkaniec może zagłosować na pięć zadań ogólnomiejskich oraz na pięć zadań lokalnych należących do dzielnicy, w której jest zameldowany. Głosowanie odbywa się drogą elektroniczną oraz papierową.

$\mathrm{W}$ początkowej fazie realizowania projektu przeprowadzono inwentaryzację internetową, która polegała na zebraniu informacji dotyczących projektów realizowanych $w$ ramach $B O$. Zorientowano się, jak wygląda sytuacja składania wniosków w ramach BO w Łodzi (rys. 1). Z wykonanej analizy wynika, że w ciągu trzech lat nastąpił gwałtowny wzrost wpływających wniosków. Można zatem stwierdzić, że zwiększa się zainteresowanie działaniami podejmowanymi w ramach $\mathrm{BO}$. 


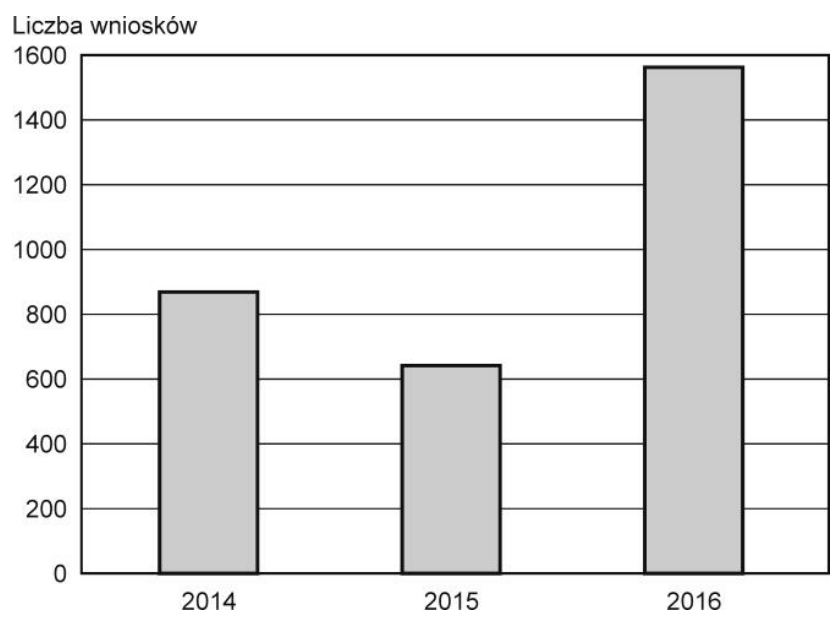

Rys. 1. Liczba wniosków złożonych w Urzędzie Miasta w ramach budżetu obywatelskiego w Łodzi w latach 2014-2016

Źródło rys. 1-15: opracowanie własne

Badania zostały przeprowadzone w pięciu wybranych obiektach rekreacyjnych występujących na terenie wszystkich dzielnic Łodzi (rys. 2). Z dzielnicy Bałuty wybrano projekt „Park Julianowski: rozbudowa XXI w.” (2016) - fot. 1 i 2 . Obejmował on wybudowanie boiska do siatkówki plażowej, siłowni, elementów zabawowych - tzw. pajęczyny, zjeżdżalni modułowej, ale także postawienie toi toiów i zdroju ulicznego, zamontowanie monitoringu, posadzenie drzew. Na dużej polanie została założona łąka ziołowo-kwiatowa, mająca - poza walorami estetycznymi - za zadanie zatrzymać wzrost pokrzyw i pałki wodnej, która opanowała ten teren. W dzielnicy Polesie zbadano obszar „Lunapark inaczej”. Zadanie to miało na celu stworzenie nowoczesnej strefy wypoczynku, rekreacji i animacji w Parku na Zdrowiu (2016) - fot. 3 i 4. Na Widzewie przyjrzano się obiektowi „małpi gaj" w Parku Podolskim na Zarzewie (fot. 5 i 6) - strefa do uprawiania street workoutu, ćwiczeń korekcyjno-ruchowych i gimnastycznych (2016). Wybrany projekt dzielnicy Górna obejmował budowę dużego i bezpiecznego placu zabaw dla dzieci na terenie Stawów Jana (2014) - fot. 7 i 8. W przypadku Śródmieścia natomiast autorki zainteresowały się budową boiska wielofunkcyjnego, boisk do siatkówki plażowej oraz ogólnodostępnej do celów rekreacyjnych siłowni plenerowej zlokalizowanej przy XXIX LO (2016). 


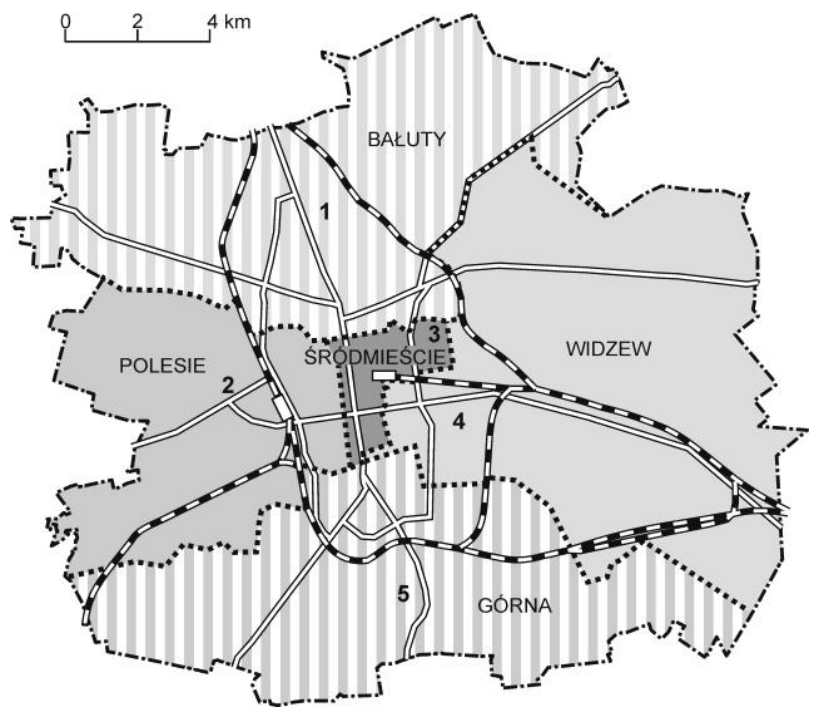

Rys. 2. Rozmieszczenie projektów rekreacyjnych zrealizowanych w Łodzi w ramach budżetu obywatelskiego, wybranych do badań terenowych

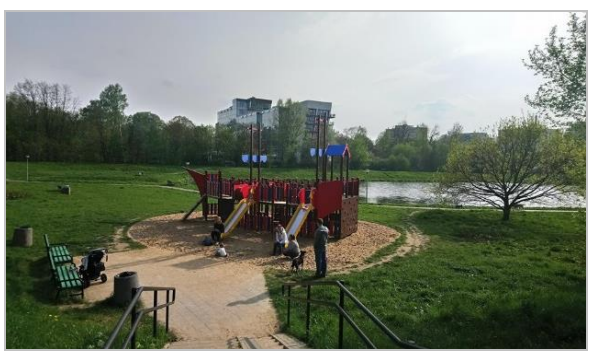

Fot. 1. Plac zabaw dla dzieci w Parku Julianowskim

Źródło: fot. 1-10 wykonanie własne

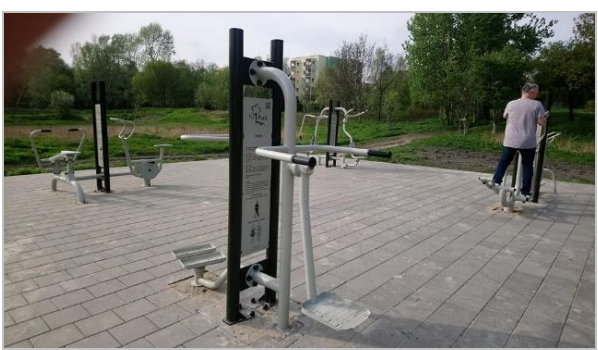

Fot. 2. FitPark na terenie Parku Julianowskiego

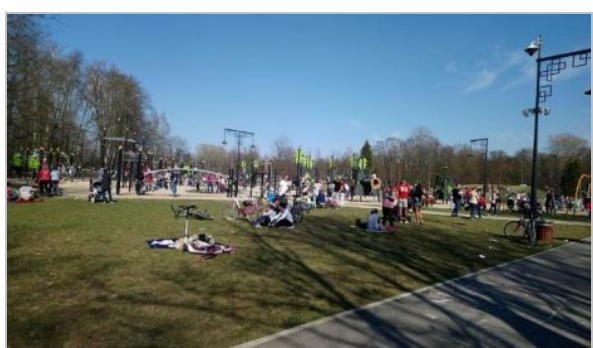

Fot. 3. „Lunapark inaczej” w Parku na Zdrowiu

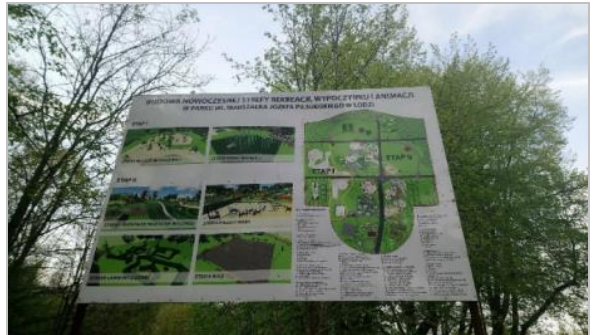

Fot. 4. Etapy realizacji projektu „Lunapark inaczej” 


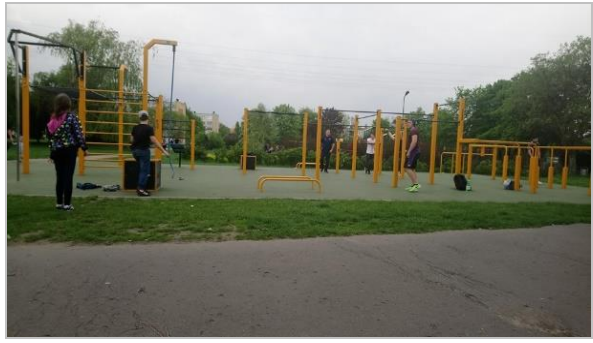

Fot. 5. „Małpi gaj” w Parku Podolskim na Zarzewie

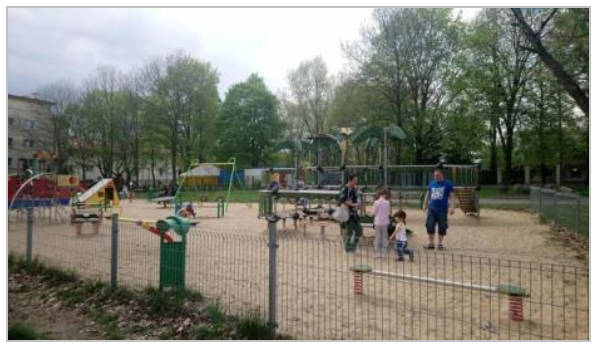

Fot. 7. Plac zabaw dla dzieci przy Stawach Jana

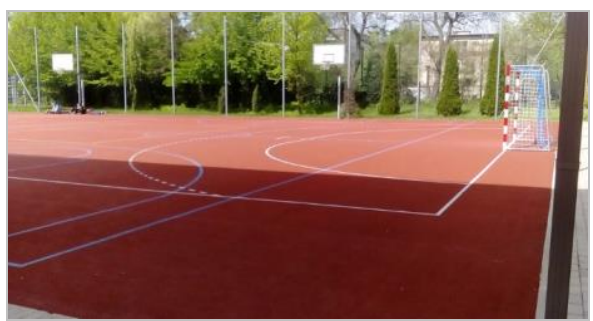

Fot. 9. Boisko wielofunkcyjne przy XXIX LO

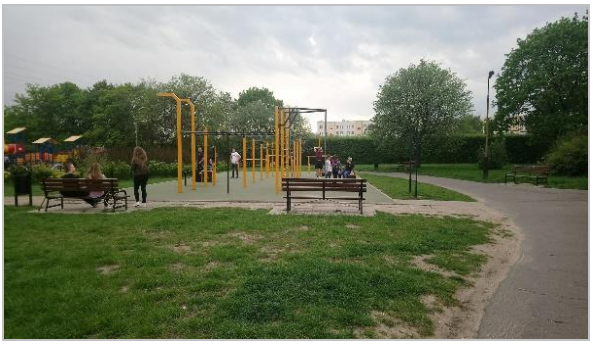

Fot. 6. Park Podolski

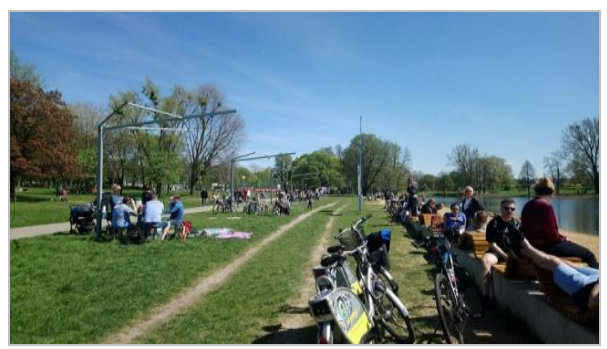

Fot. 8. Stawy Jana

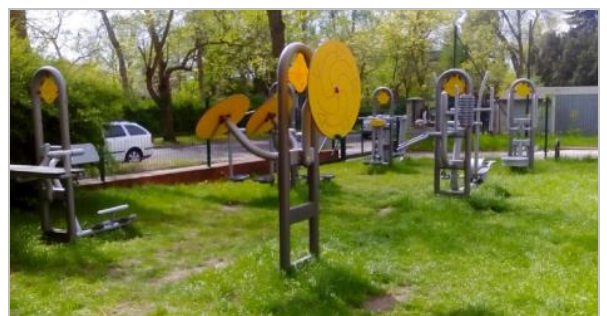

Fot. 10. Ogólnodostępna siłownia plenerowa do celów rekreacyjnych przy XXIX LO

Badania ankietowe (200 wywiadów kwestionariuszowych) przeprowadzono na terenie wybranych obiektów: w Parku Julianowskim, w Parku na Zdrowiu w pobliżu strefy „Lunapark inaczej”, przy „małpim gaju” w Parku Podolskim na Zarzewie oraz w pobliżu placu zabaw dla dzieci na terenie Stawów Jana. W każdym $\mathrm{z}$ wymienionych miejsc przeprowadzono 50 wywiadów kwestionariuszowych. Przy XXIX LO, gdzie powstało boisko wielofunkcyjne, boisko do siatkówki plażowej oraz ogólnodostęp- 
na siłownia plenerowa do celów rekreacyjnych, nie udało się przeprowadzić wywiadów kwestionariuszowych. Ze względu na lokalizację wybranego obiektu przy szkole przychodziła tam głównie uczęszczająca do niej młodzież, a badania dotyczyły wyłącznie dorosłych użytkowników obiektów.

Na podstawie zgromadzonych materiałów sporządzono wykresy, aby prosty i czytelny w sposób przedstawić wyniki przeprowadzonych badań. Tematem artykułu jest budżet obywatelski jako narzędzie kreowania przestrzeni rekreacyjnej Łodzi, zatem konieczne było dokonanie analizy, która ukaże, jaką część stanowią projekty związane z przestrzenią rekreacyjną. Dokładny obraz przedstawiono na rys. 3, z którego wynika, że projektów związanych z rekreacją jest więcej niż pozostałych przedsięwzięć. Na rys. 4 został zaprezentowany rozkład projektów realizowanych w ramach BO w Łodzi, związanych z przestrzenią rekreacyjną $w$ latach 2014-2018.

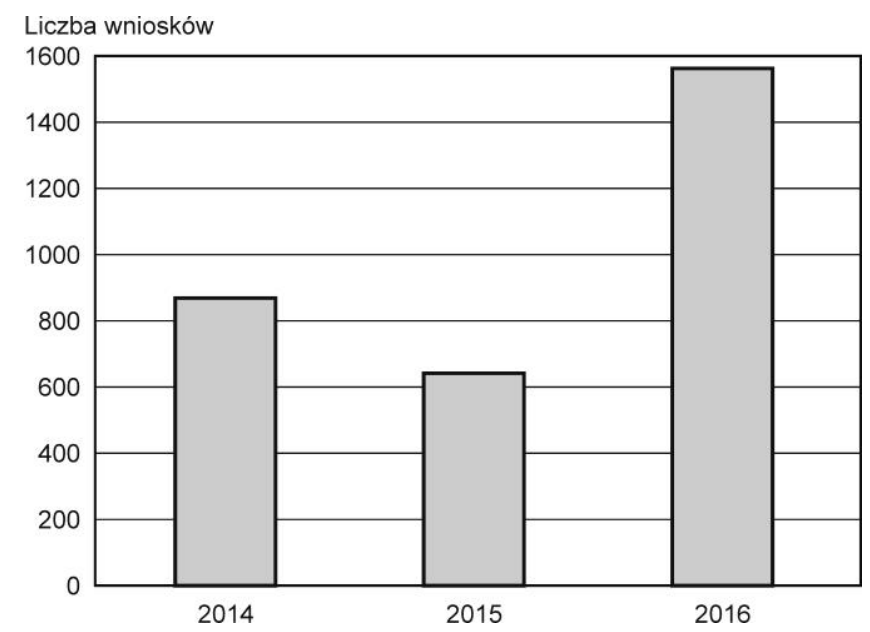

Rys. 3. Skierowane do realizacji projekty wykorzystania budżetu obywatelskiego związane $\mathrm{z}$ przestrzenią rekreacyjną Łodzi na tle wniosków $z$ lat 2014-2016

Z mapy (rys. 4) wynika, że największe skupisko zrealizowanych projektów znajduje się $\mathrm{w}$ centrum miasta oraz w pobliżu terenów zielonych - parków, skwerów itp. Są to głównie inwestycje obejmujące budowę wielofunkcyjnych boisk, siłowni plenerowych, placów zabaw, które często zlokalizowane są w sąsiedztwie szkół. 


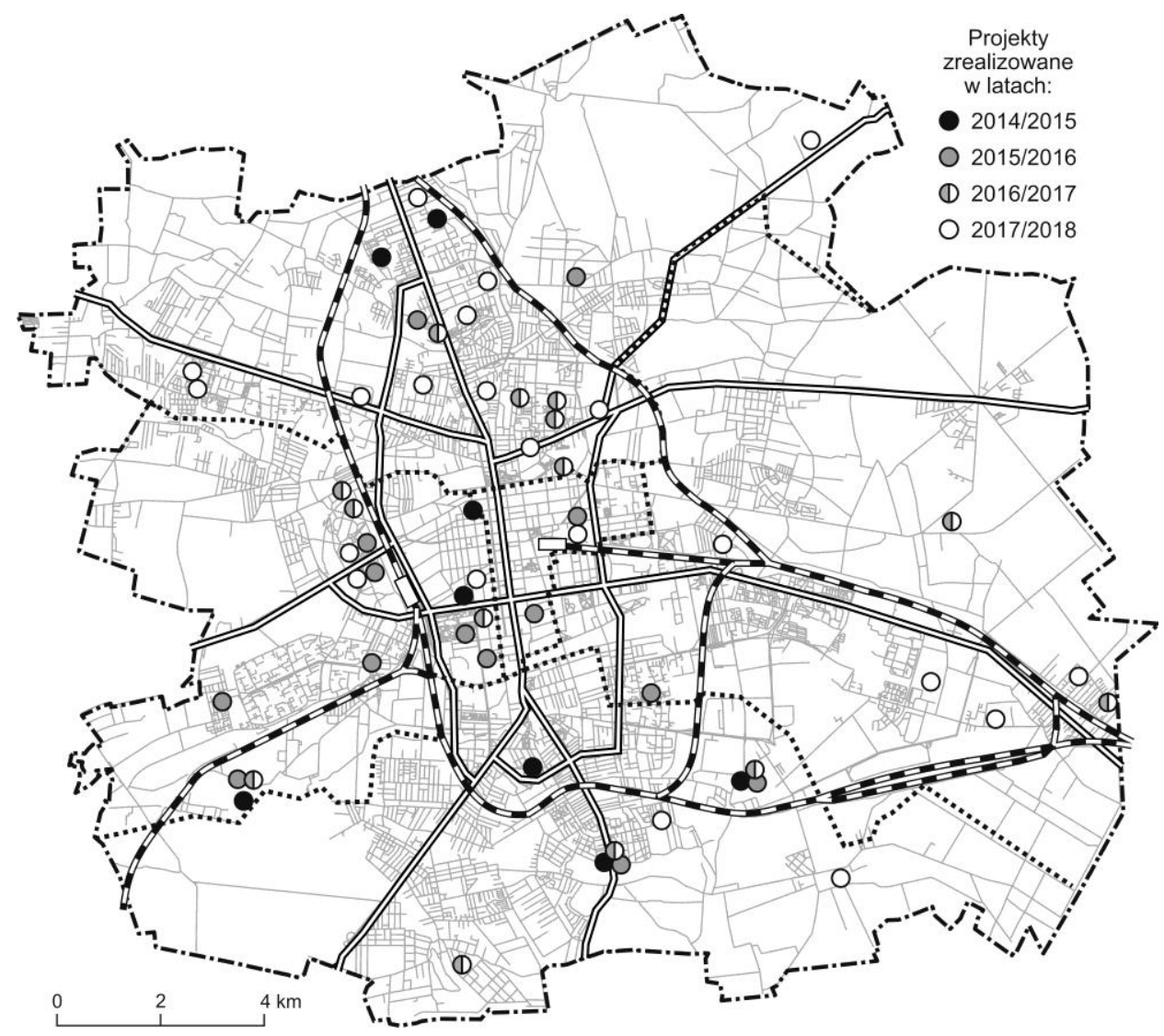

Rys. 4. Mapa projektów realizowanych w ramach budżetu obywatelskiego w Łodzi, związanych z przestrzenią rekreacyjną w poszczególnych latach w okresie 2014-2018 r. Źródło: opracowanie własne na podstawie mapy udostępnionej na stronie BO w Łodzi

W odczuciu autorek efekty głosowania na BO w Łodzi wydawały się na tyle atrakcyjne, że zdecydowano się je porównać do innych miast. Rysunek 5 ukazuje, że pod względem angażowania się $\mathrm{w}$ głosowanie na te projekty na przestrzeni kilku już lat mieszkańcy Łodzi zajmują pierwsze miejsce wśród obywateli innych miast Polski, które wprowadziły proces BO. Nie do końca są jasne przyczyny dużego zróżnicowania w skali kraju. Być może wynika to z faktu, że Łódź potrzebowała wielu inwestycji w tereny rekreacyjne, ze względu m.in. na swój dotychczasowy słaby wizerunek w tym zakresie. $Z$ biegiem czasu zauważalna staje się jednak jego poprawa, następująca dzięki dużym inwestycjom realizowanym w mieście. 
Liczba oddanych głosów w tys.

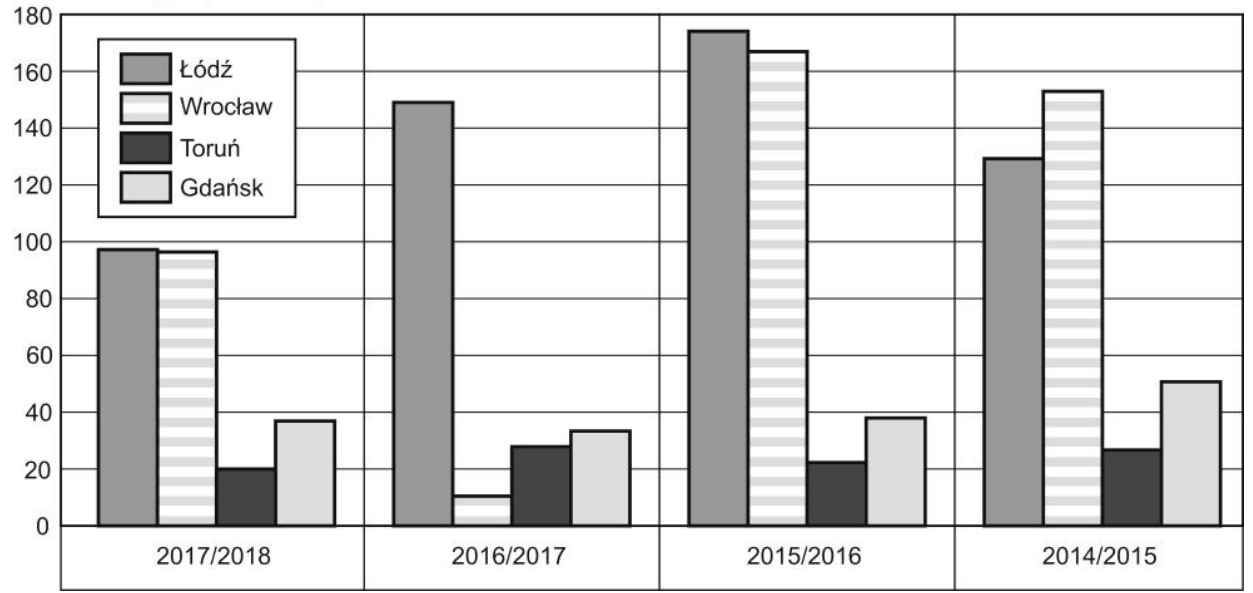

Rys. 5. Liczba oddanych w Łodzi głosów na projekty $\mathrm{z}$ budżetu obywatelskiego na tle innych miast

Źródło: opracowanie własne na podstawie dokumentacji budżetu obywatelskiego

Przeprowadzając badania terenowe, pytano użytkowników wspomnianych obszarów, czy wiedzą, skąd zostały pozyskane pieniądze na powstały obiekt. Wyniki zebranych odpowiedzi przedstawiono na rys. 6 - widać, że spora część odwiedzających orientuje się, z jakich środków zostały sfinansowane strefy rekreacyjne, z których korzystają. Spośród czterech zbadanych obiektów najbardziej wyróżnia się pod tym względem Park Julianowski, jako że 40 osób na 50 ankietowanych zadeklarowało znajomość źródła finansowania modernizacji tego terenu. Zapewne wynika to ze śledzenia przez

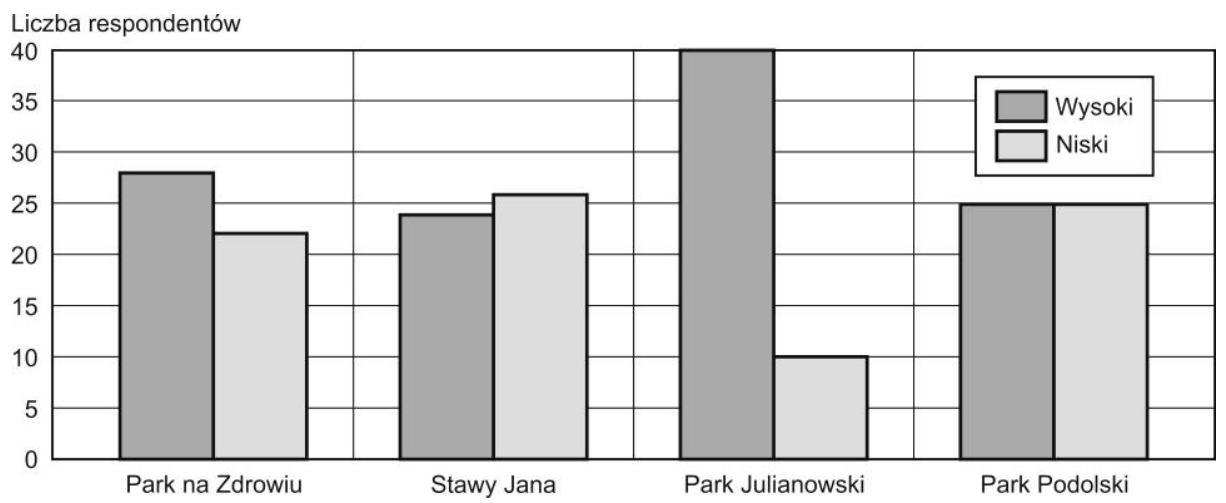

Rys. 6. Stan wiedzy użytkowników badanych terenów rekreacyjnych Łodzi na temat źródła finansowania znajdujących się na nich obiektów 
odwiedzających te obiekty zamieszczonych w widocznych miejscach na ich terenie tablic informacyjnych.

Takie informacje trafiają do ludzi, dzięki czemu można się spodziewać, że w przyszłości mieszkańcy zaczną angażować się w głosowanie lub zgłaszanie projektów (jeśli do tej pory tego nie robili).

Zadano też pytanie ogólne dotyczące tego, czy lokalna społeczność akceptuje i pochwala działania wykorzystujące środki BO. Za pomocą wykresu (rys. 7) zaprezentowano uzyskane odpowiedzi, potwierdzające, że znaczna większość respondentów poparła proces wdrożenia BO jako źródła finansowania wskazanych przez obywateli terenów wypoczynkowych (rys. 7). Dzięki tym działaniom mieszkańcy poszczególnych osiedli zyskali bowiem przestrzeń rekreacyjną. Jedynym miejscem niechlubnie wyróżniającym się spośród badanych obiektów są Stawy Jana. W tym przypadku brak akceptacji dla inwestycji finansowanej przez BO może wynikać $\mathrm{z}$ faktu, że w porównaniu z pozostałymi inwestycjami znajdujący się na tym terenie plac zabaw był znacznie mniejszy i nie posiadał zbyt licznych atrakcji dla dzieci w różnym wieku.

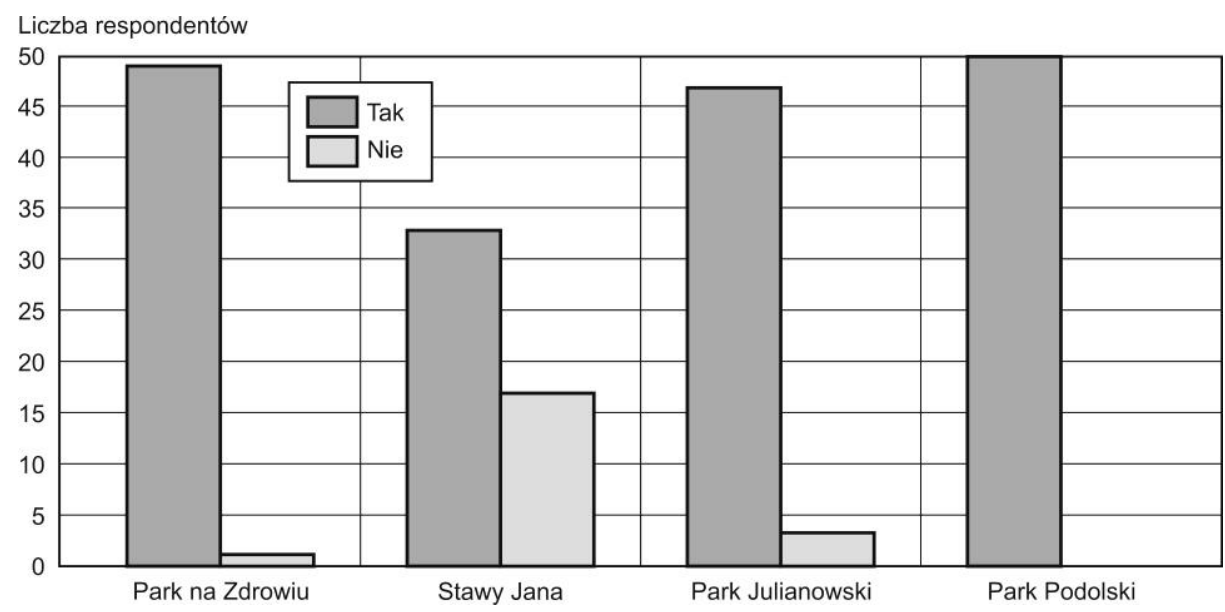

Rys. 7. Akceptacja procesu budżetu obywatelskiego przez respondentów w Łodzi jako źródła finansowania badanych projektów

Za pomocą wykresu (rys. 8) przedstawiono częstotliwość odwiedzania badanych terenów. Wynika z niego, że osoby biorące udział w badaniu często odwiedzają parki. Większość respondentów z Parku Podolskiego odpowiedziała, że odwiedza park codziennie. Zapewne ma to związek $z$ faktem, że znajduje się on wśród bloków mieszkalnych, w związku z czym 
wielu mieszkańców nie ma czasem innej drogi dotarcia chociażby na przystanek komunikacji miejskiej czy do sklepu, jak właśnie przez park. W Parku Julianowskim natomiast najwięcej ankietowanych osób przebywa od trzech do czterech razy $\mathrm{w}$ tygodniu. Zazwyczaj są to rodzicie $\mathrm{z}$ dziećmi bądź dziadkowie z wnukami, na tym terenie powstało bowiem kilka miejsc przyjaznych dzieciom. Do Stawów Jana respondenci docierają dwa, trzy razy w miesiącu. Na taką częstotliwość korzystania z tych obiektów może mieć wpływ fakt, że jest to miejsce oddalone od bloków, kamienic czy domków jednorodzinnych. Stawy Jana stanowią obszar, na który przybywają ludzie z okolic i z całej Łodzi. Podobnie jest z Parkiem na Zdrowiu, służącym wszystkim mieszkańcom miasta, ale większość badanych odwiedza go raz na kilka miesięcy.

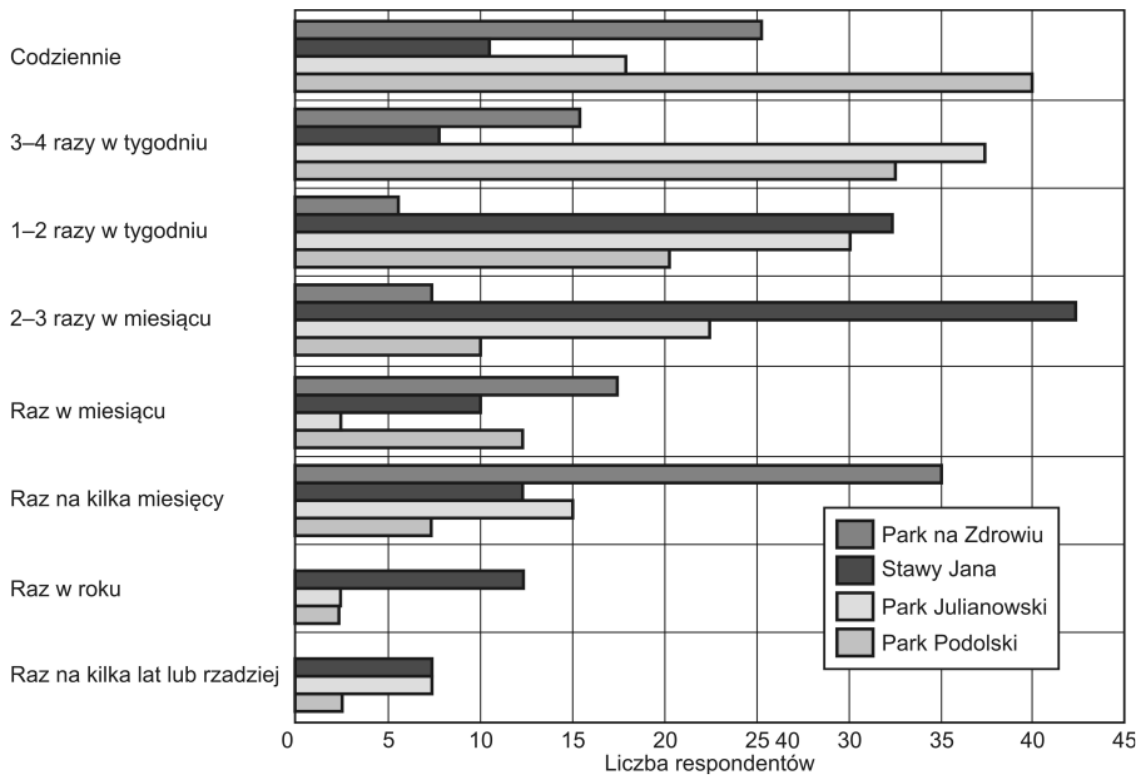

Rys. 8. Częstotliwość odwiedzania przez respondentów badanych terenów rekreacyjnych

Wizyta w parku według respondentów trwa zazwyczaj od jednej do dwóch godzin, co wydaje się dobrym wynikiem badań nad czasem spędzanym na terenach obiektów powstałych lub zagospodarowanych $\mathrm{w}$ ramach procesu BO w Łodzi (rys. 9). 
Ankietowana społeczność swój wolny czas lubi spędzać w zadbanych i atrakcyjnych miejscach, co potwierdzają dane widniejące na rys. $10 \mathrm{i} 11$.

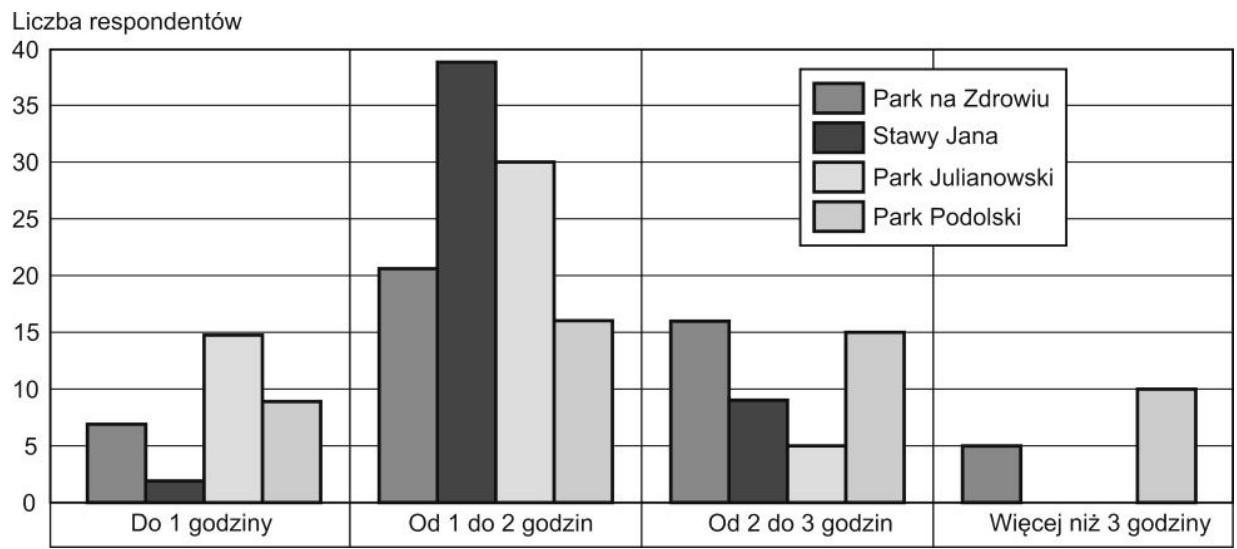

Rys. 9. Ilość czasu spędzanego przez respondentów na badanych terenach rekreacyjnych

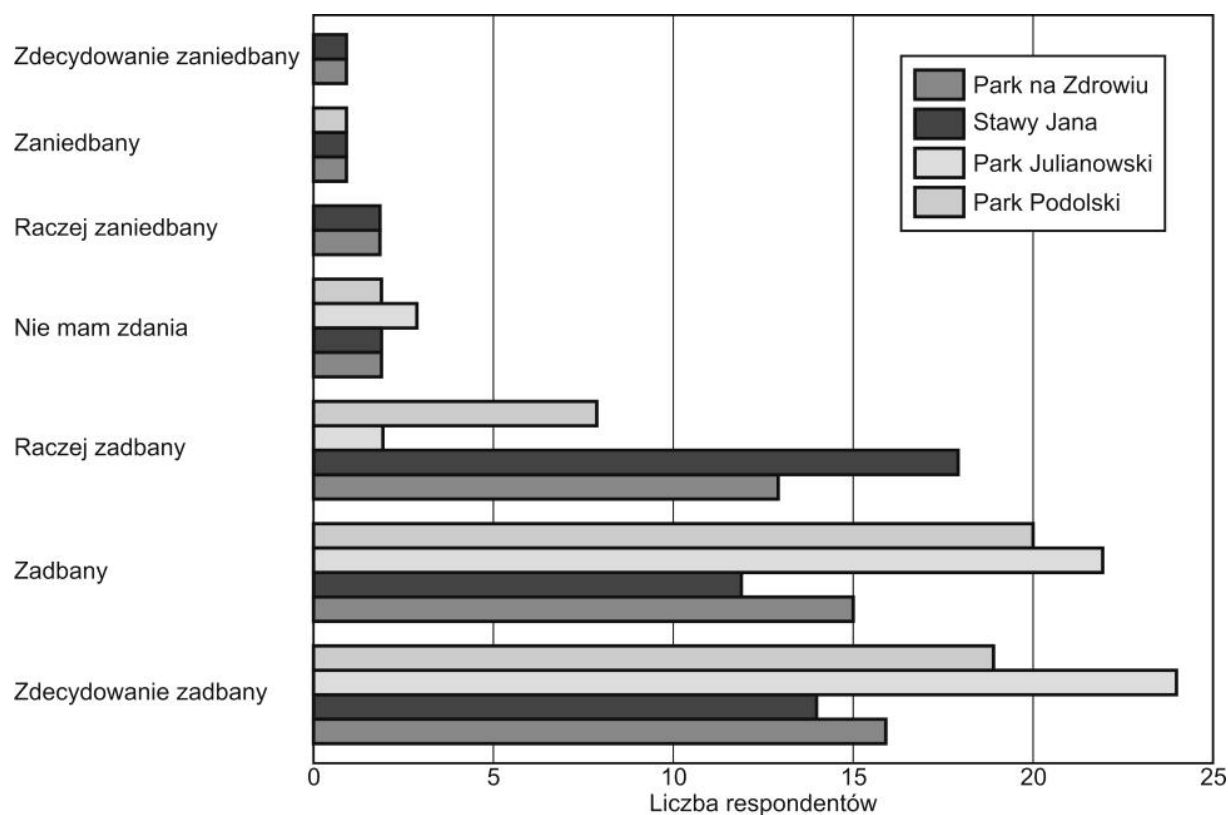

Rys. 10. Ocena respondentów dotycząca poziomu zadbania badanych terenów rekreacyjnych 


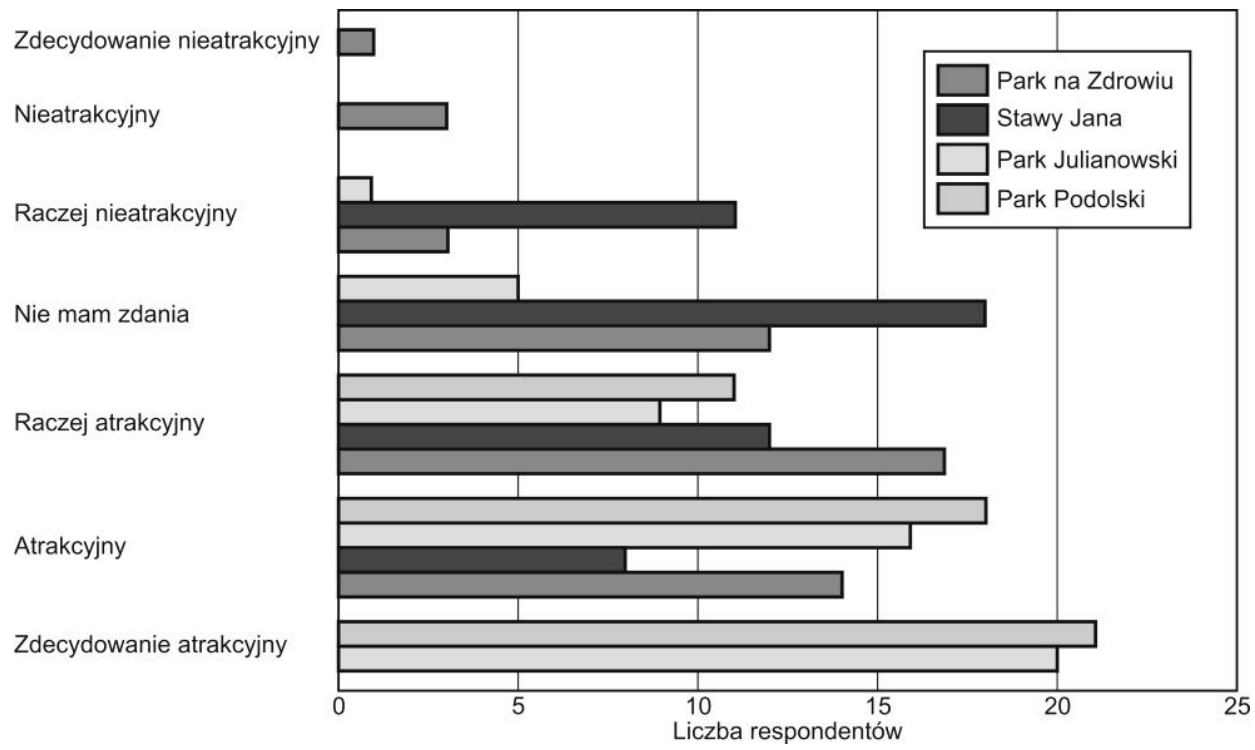

Rys. 11. Ocena respondentów dotycząca poziomu atrakcyjności badanych terenów rekreacyjnych

W związku z tym, że większość analizowanych przez autorki miejsc obejmowała place zabaw i obiekty sportowe, zdecydowano się zapytać ankietowanych o ocenę wyposażenia tych miejsc. Za pomocą wykresu (rys. 12) wykazano, że respondenci są zadowoleni z wyposażenia użytkowanych terenów w przyrządy do zabaw dla najmłodszych.

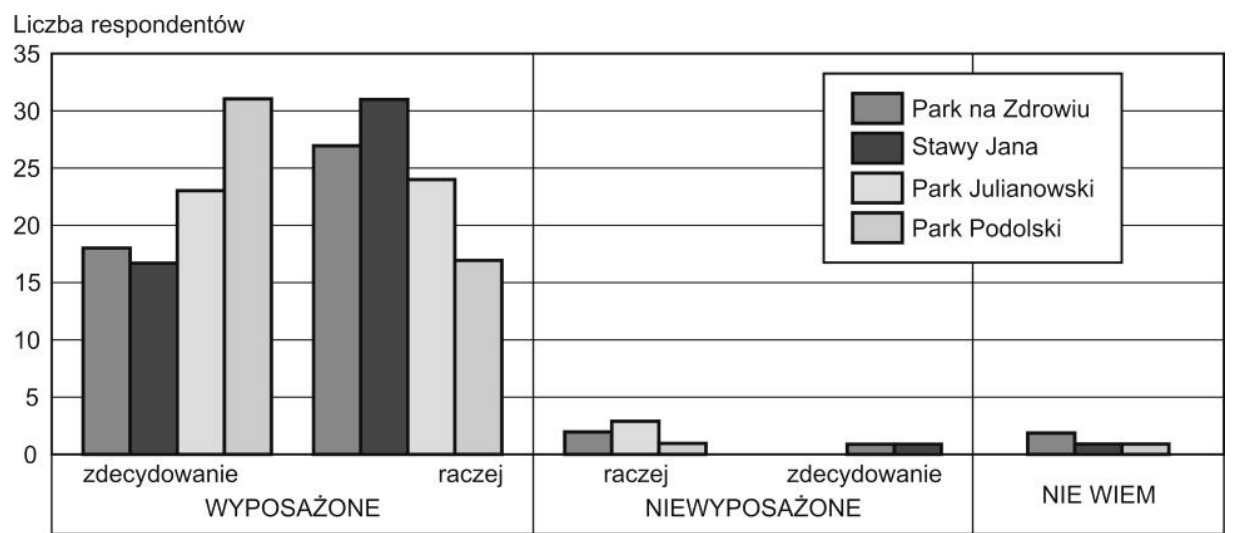

Rys. 12. Ocena respondentów dotycząca wyposażenia badanych obiektów rekreacyjnych w urządzenia do zabaw dla dzieci 
Na rys. 13 przedstawiono poziom satysfakcji ankietowanych z wyposażenia badanych terenów rekreacyjnych w Łodzi w ramach BO. Jak pokazuje wykres, w większości respondenci są usatysfakcjonowani wyposażeniem użytkowanego przez nich terenu.

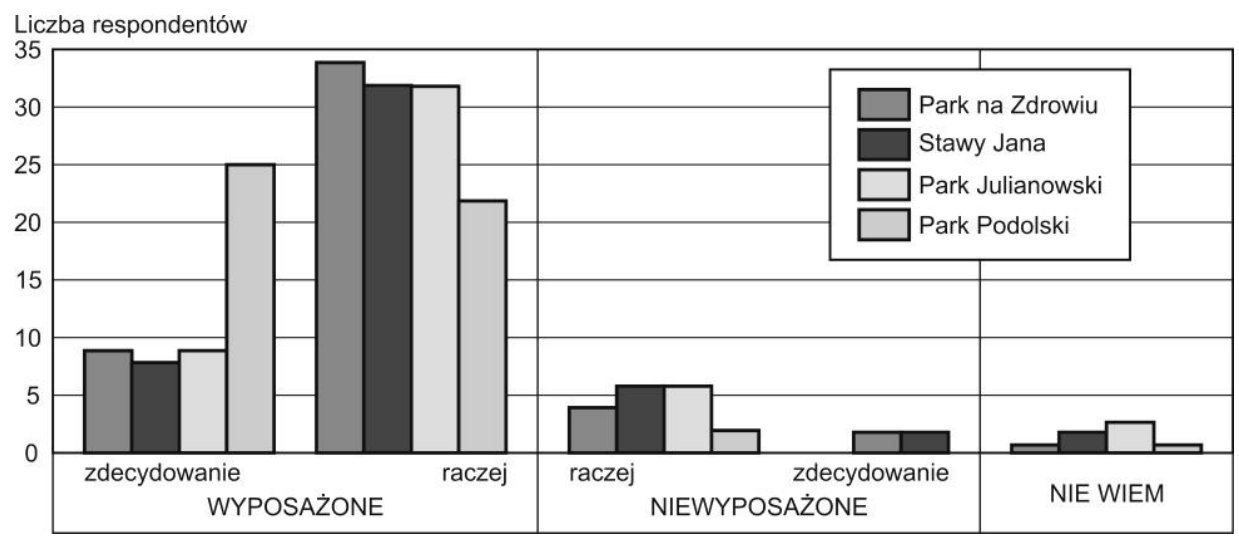

Rys. 13. Ocena respondentów dotycząca wyposażenia badanych miejsc rekreacyjnych w obiekty sportowe

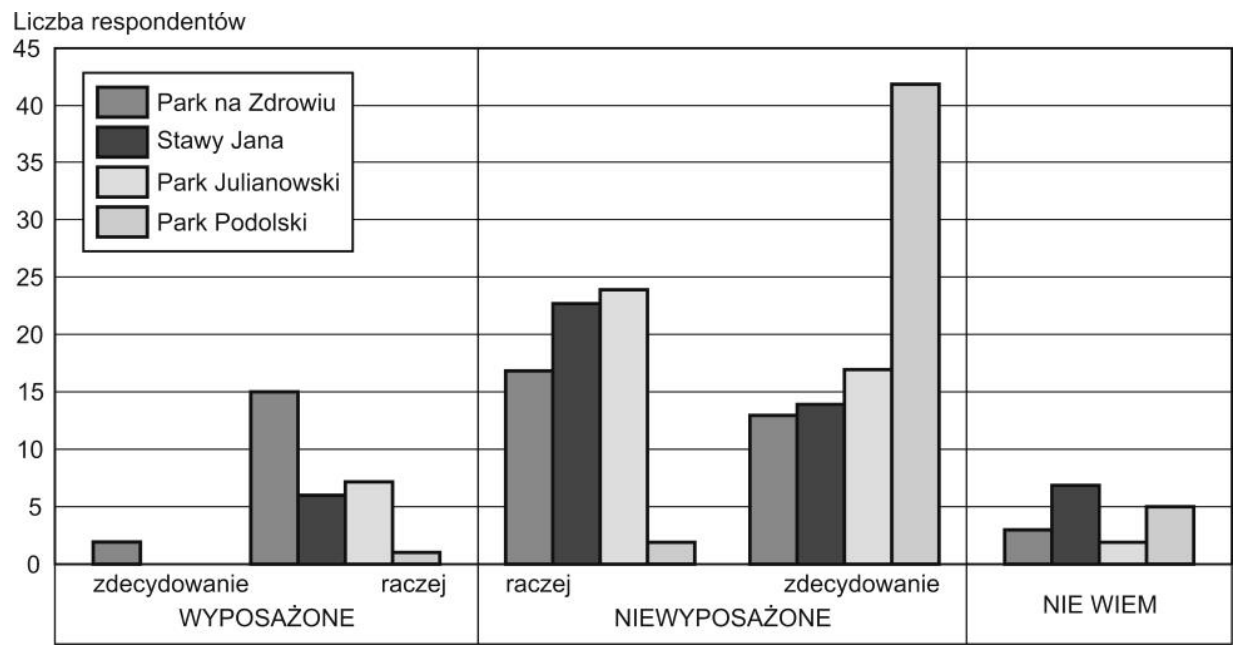

Rys. 14. Ocena respondentów dotycząca wyposażenia badanego miejsca rekreacji w obiekty gastronomiczne

W atrakcyjnych dla badanej społeczności miejscach coraz częściej spotyka się punkty małej gastronomii. Niestety w wybranych przez autorki obiektach według ankietowanych takich punktów brakowało. Być może pojawią się one $\mathrm{w}$ okresie wakacyjnym, kiedy można oczekiwać nie tyl- 
ko, że miejskie tereny rekreacyjne będzie odwiedzało więcej osób (rys. 14), ale również, że będą one dłużej przebywać w tych miejscach.

Podobnie jest $\mathrm{z}$ pytaniem o miejsca zadaszone i przeznaczone do organizowania pikników na badanych obszarach rekreacji w Łodzi. Znaczna część ankietowanych odpowiedziała, że odwiedzane przez nich obiekty nie są wyposażone w tego typu infrastrukturę (rys. 15).

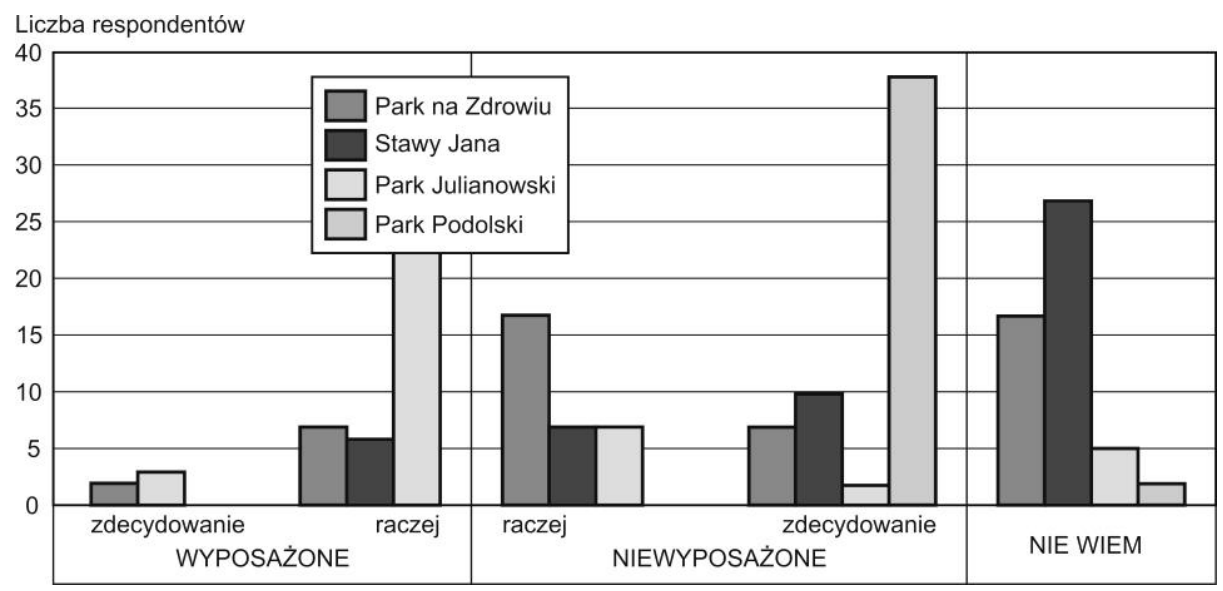

Rys. 15. Ocena respondentów dotycząca wyposażenia rekreacyjnych obiektów badań w zadaszone miejsca piknikowe

Z przeglądu i analizy rys. 5-15 wynika, że wybrane do badań projekty, zrealizowane $\mathrm{w}$ ramach procesu budżetu obywatelskiego, skupiały się przede wszystkim na zapewnieniu mieszkańcom terenów rekreacyjnych - urządzeń do zabawy dla dzieci oraz przyrządów do ćwiczeń, które w założeniu służą polepszaniu kondycji fizycznej dorosłym. Część z tych projektów będzie dalej rozbudowywana, ponieważ stanowią one zadania ogólnomiejskie, które spotkały się z dużym zainteresowaniem i poparciem. Warto więc zastanowić się nad uatrakcyjnieniem tych miejsc pod względem ich ogólnego zagospodarowania sprzyjającego satysfakcjonującej rekreacji czynnej mieszkańców miast.

\section{Podsumowanie}

Przeprowadzone badania terenowe nad wdrażanym w Łodzi od 2014 r. procesem tworzenia budżetu obywatelskiego pozwoliły na wysnucie kilku istotnych wniosków. Ustalono przede wszystkim, że mieszkańcy Łodzi 
zajmują pierwsze miejsce wśród mieszkańców miast Polski pod względem angażowania się $\mathrm{w}$ głosowanie na projekty finansowane $\mathrm{z}$ budżetu obywatelskiego.

Postawione we wstępie hipotezy - pierwsza i druga (BO w dużym stopniu przyczynia się do kreowania przestrzeni rekreacyjnej Łodzi; mieszkańcy miasta podczas głosowania $\mathrm{w}$ ramach budżetu obywatelskiego najchętniej wybierają zadania związane $\mathrm{z}$ zagospodarowaniem przestrzeni rekreacyjnej) zostały potwierdzone, ponieważ w toku badań ustalono, że budżet obywatelski ma duże znaczenie w kreowaniu przestrzeni rekreacyjnej Łodzi. Według respondentów władze miasta odpowiednio wykorzystują środki z budżetu obywatelskiego, aby uatrakcyjnić jego przestrzeń rekreacyjną, a tym samym czas wolny mieszkańców. Podczas głosowania w ramach budżetu obywatelskiego badani najchętniej wybierali zadania związane z zagospodarowaniem przestrzeni rekreacyjnej.

Hipoteza trzecia - korzystający z terenów rekreacyjnych, finansowanych z BO, nie mają świadomości, z jakich środków zostały one utworzone - nie została potwierdzona, ponieważ wykazano, że dzięki zamieszczaniu tablic informacyjnych większość badanych osób dowiaduje się, skąd pozyskano pieniądze na budowę (modernizację) i wyposażenie poszczególnych terenów/obiektów rekreacyjnych, co może skutkować zaangażowaniem większej liczby mieszkańców w latach następnych.

Ustalono także, że użytkownicy badanych terenów rekreacyjnych spędzają na nich czas wolny, głównie spacerując, odwiedzając z dziećmi place zabaw oraz jeżdżąc na rowerze. Miejsca te są użytkowane przede wszystim przez osoby młode oraz rodziny z dziećmi. Kilka obiektów rekreacyjnych powstałych ze środków budżetu obywatelskiego zyskało na tyle dużą popularność wśród mieszkańców Łodzi, że w kolejnych edycjach wygrywały projekty, których celem była realizacja następnych etapów powstałych inwestycji.

\section{Bibliografia}

Kębłowski, W. (2013). Budżet partycypacyjny: krótka instrukcja obstugi. Warszawa: Instytut Obywatelski.

Kębłowski, W. (2014). Budżet partycypacyjny: ewaluacja. Warszawa: Instytut Obywatelski.

Kraszewski, D., Mojkowski, K. (2014). Budżet obywatelski w Polsce. Warszawa: Fundacja im. Stefana Batorego.

Łódzki budżet obywatelski - o projekcie. Pobrane z: https://uml.lodz.pl/dla-mieszkan-cow/ lodzianie-decyduja/budzet-obywatelski/ (8.01.2019). 
Migdał, K. (2011). Psychologia czasu wolnego. Warszawa: Almamer.

Pięta, J. (2008). Pedagogika czasu wolnego. Warszawa: Almamer.

Sobol, A. (2017). Budżet obywatelski jako narzędzie rozwoju lokalnego. Katowice: Wydawnictwo Uniwersytetu Ekonomicznego w Katowicach.

\title{
BUDŻET OBYWATELSKI JAKO NARZĘDZIE KREOWANIA PRZESTRZENI REKREACYJNEJ ŁODZI
}

\begin{abstract}
Abstrakt: Artykuł dotyczy budżetu obywatelskiego, który przyczynia się do kreowania przestrzeni rekreacyjnej Łodzi. We wstępie zamieszczono cele pracy, sformułowano trzy hipotezy naukowe oraz przedstawiono wykorzystane metody i narzędzia badawcze. W kolejnych częściach pracy omówiono historię budżetu obywatelskiego oraz wyjaśniono sens jego ustanowienia. Następnie dokonano analizy wykorzystywania budżetu obywatelskiego do realizacji projektów związanych z zagospodarowaniem terenów służących wypoczynkowi mieszkańców Łodzi na podstawie zgromadzonych materiałów oraz przeprowadzonych badań terenowych.
\end{abstract}

Słowa kluczowe: budżet obywatelski, przestrzeń rekreacyjna, czas wolny, Łódź.

\section{THE PARTICIPATORY BUDGET AS A TOOL FOR THE CREATION OF A RECREATION SPACE IN LODZ}

\begin{abstract}
This article pertains to participatory budget, which allows for the creation of the recreation space in Lodz. The introduction presents the aims of work, three research hypotheses, as well as the methods and tools used by the authors. In the subsequent parts of the article, the authors discuss the history of the participatory budget and explain its procedures. Next, an analysis of the participatory budget is presented, based on the collected materials and local research. The study is focused on tourism issues.
\end{abstract}

Keywords: participatory budget, recreation space, leisure, Łodz. 